\title{
The Question of Ancient Scandinavian Cultic Build- ings: with Particular Reference to Old Norse hof ${ }^{1}$
}

\author{
OLOF SUNDQVIST \\ University of Gävle
}

\begin{abstract}
The article focuses on the question of ancient Scandinavian cultic buildings, with particular reference to the concept Old Norse hof. I survey the semantics of this term in written sources, in poetic traditions, in the Sagas of the Icelanders and in place names. My hypothesis is that the term does not refer to a static phenomenon, but rather its meaning varies across different sources and contexts. It is therefore often difficult to apply it as a general concept, or to connect it with a specific type of archaeological find or structure, as has occasionally been the case in the archaeology of religion.
\end{abstract}

Keywords: archaeology of religion, multi-functional halls, cultic buildings, Old Norse hof

A controversial question in the study of ancient Scandinavian religion has been the existence of pre-Christian 'temples', more specifically of cultic buildings. This question is related to the archaeology of religion, and has involved both archaeologists and historians of religions over more than 150 years. As early as 1835, Jakob Grimm argued, with support from classical sources, that pre-Christian cultic acts among the Germanic people were mostly performed out-doors, in connection with sacred groves. Eventually, other scholars also noted that 'temples' were visible in Old Norse sources and in place-names referring to pre-Christian Scandinavia (e.g. Keyser 1847; Thümmel 1909; M. Olsen 1926; Ohlmarks 1936; Gehl 1941; de Vries 1970). According to these sources, the ancient Scandinavians had buildings called hof, hörgr, goðahús and blóthús. Images and sacred objects were kept in these houses, and it was also there that the Scandinavians made sacrifices to their gods and celebrated their religious feasts. Viking Age finds at an excavation at Hofstaðir, Mývatnssveit, in Northern Iceland in 1908 confirmed that the descriptions of the 'temples' in the Sagas of the Icelanders were reliable and could be supported with archaeological evidence (Bruun \& Jónsson 1909).

1 This essay was prepared with the financial support of Riksbankens Jubileumsfond in Sweden. 
Olaf Olsen's source-critical investigation, Hørg, hov og kirke (1966), however, involved a radical adjustment of this scholarly position. Olsen argued that the descriptions of the 'temples' (hof sg.) in the Old Norse traditions was not supported by the evidence from archaeological materials discovered at so-called hof-settlements (hovtomter) in Iceland. The descriptions of 'temples' in the Old Norse Sagas were actually projections of the medieval authors' experience of churches. The 'temples' discovered in archaeological excavations in Iceland, such as the one at Hofstaðir, were actually the dwelling-houses or halls of the chieftains. They were probably the site of ceremonial feasts, but also of other types of activities, some of which could not be considered to be religious.

Olsen's dissertation exerted a strong influence on research in the following decades. His interpretation influenced archaeologists, not least by his discussion of Late Iron Age banqueting halls. These buildings were often interpreted as multi-functional arenas for the elite. The finds discovered in connection with them, for instance gold-foil figures (Swedish guldgubbar) and ceremonial glass, indicate that rituals had also occasionally been performed there. Such halls had been erected at aristocratic central places of varying local, regional and trans-regional significance, such as Dejbjerg, Gudme and Lejre in Denmark, Vallhagar (Gotland), Uppsala, Helgö and Slöinge in Sweden, and Borg in Norway (see Figure 1) (e.g. Herschend 1993; 1995; 1997; 1998; 1999). Historians of religions were also inspired by Olsen's study, arguing that the hof buildings mentioned in the Kings' Sagas and the Sagas of the Icelanders should be interpreted as multi-functional halls (e.g. Hultgård 1996).

The most recent scholarship, however, indicates that the debate concerning more specific cultic buildings must be resumed. New archaeological finds suggest that more specific and exclusive cultic buildings may have existed in Late Iron Age Scandinavia. At several excavations sites in Denmark and Sweden, traces of smaller buildings have been discovered, occasionally adjacent to huge halls. The context of the finds testifies that these buildings had ritual functions. Of specific importance is the small house $(5.5 \times 7 \mathrm{~m})$ on the Viking Age chieftain farm at Borg, in Östergötland, Sweden (see Figure 2). This house appeared in a context of finds that make a cultic interpretation most plausible (Nielsen 1996). The building had stood in a stone-paved courtyard, where approximately $75 \mathrm{~kg}$ of unburned bones were discovered in connection with a rock. These bones have been interpreted as the remains of animal sacrifices. Beside the rock was a depot containing almost a hundred amulet rings. At the central place of Uppåkra, outside Lund, Scania, 
a possible cult house $(13,5 \times 6 \mathrm{~m})$ was explored (see Figure 3) (Larsson \& Lenntorp 2004). This house had first been built during the Roman Iron Age, and was rebuilt in several phases up until the Viking Period. The specific finds, including gold-foil figures, a glass bowl and a gilded silver beaker, indicate that this house may have been a more exclusive and specific cultic building. Separate smaller buildings, located beside Iron Age halls and surrounded by enclosures, have been found at Lejre and Tissø in Denmark and at Järrestad in South-Eastern Scania. They have also been interpreted as more specific cultic buildings (see Figure 4) (see Christensen 1991; 1997; Jørgensen 1998; 2002; Söderberg 2005).

In the light of these new archaeological observations, we have to assume the existence of at least two types of cultic buildings in Late Iron Age Scandinavia. First we have the multi-functional and aristocratic representation halls built at central places such as Old Uppsala, Gudme, Helgö and Slöinge. In addition there were probably also smaller cultic houses, such as the one found at Borg, Östergötland. These smaller houses most likely had a more specific religious function and were occasionally erected just beside the large Iron Age halls, as seen in Lejre, Tissø and Järrestad.

In connection with the smaller and more specific cultic buildings, scholars have been searching for concepts in the Old Norse literature which correspond to the archaeological finds. These smaller buildings have been regarded as equivalent to the hörgr appearing in the textual sources, while the fenced and ritual areas around them have been interpreted as a hof (see e.g. Jørgensen 1998; 2002; Andrén 2002, 315f.; Söderberg 2005, 109, 195f.). Even if these interpretations are not totally unreasonable, ${ }^{2}$ they have weak support in the ancient Icelandic literature. The idea that hörgr designates a house can only be seen in a few (and problematic) texts. The manuscript known as the Codex Regius of the Snorra Edda, for example, mentions that the gods built a hall (salr). This was the hörgr that belonged to the goddesses. The building (hús) was called Vingólf. ${ }^{3}$ However, if we go to the oldest manuscript, the Codex Upsaliensis, the hörgr in the same passage designates a construction inside the hall, not the building itself. ${ }^{4}$ The other instance where hörgr refers to a house is in the Ældre Gulatings Law. According to this

2 Scholars have shown that the place name hov sometimes refers to 'farm, noble farm' or 'the farm par preference'. See Vikstrand 2001, 260. Old Norse hörgr may in a few texts designate a building. See e.g. Rostvik 1967; Vikstrand 2001, 211.

3 Annan sal gerðu peir, pat var hörgr, er gyðjurnar áttu, ok var hann allfagr, pat hús kalla men Vingólf. Cod. Reg. Edda (Arnamagn.) I, 62.

4 ... annan sal gerðu peir er horg var $i$... See Cod. Ups. Edda (Arnamagn.) I, 260. 
text, it is forbidden to build a house and call it a hörgr. ${ }^{5}$ The interpretation of this reference has also been regarded as problematic in previous scholarship (see e.g. Olsen 1966, 106). In religious contexts the concept hörgr is mostly given the meaning 'outdoor sanctuary' or 'stone altar' (see e.g. Völuspá 7; Hyndloliód 10; see also La Farge \& Tucker 1992, 133).

The term in the written sources that most frequently refers to cultic buildings is the Old Norse hof (Old Swedish hov). Old Norse dictionaries, however, do not give a thorough description of the character of these houses. According to the Norrøn ordbok, for instance, it means 'heidnisk gudehus, hov, tempel' (Heggstad et al. 1993). The terminological aspect of cultic houses thus needs to be further elucidated, not least in the context of the new archaeological finds.

In what follows I restrict the investigation to the concept of the hof. My purpose is to survey and outline the semantics of this term in the written sources, in the poetic traditions, in the Sagas of the Icelanders and in place names. My hypothesis is that this term does not refer to a static phenomenon; its meaning varies within different sources and contexts. It is therefore often difficult to apply the term as a general concept, or to connect it with a specific type of archaeological find or structure.

\section{The Case of Old Norse hof}

According to linguistic scholars, the word hof originally had the meaning 'height, hill'; it was only later that it developed the meaning 'chieftain farm' or 'cultic building' (see e.g. Andersson 1992; Brink 1996a; Vikstrand 2001, 253; de Vries 1961; SOL, 131f.). ${ }^{6}$ Theophoric place names, however, testify that as early as the Late Iron Age (400-1100) hof could have had a sacred meaning, as for instance in Froyshov ('the god Freyr's hof'), Norderhov ( $\left.{ }^{*} N(j) æ r ð a r h o f\right)$ ('the goddess *N(j)ærð's hof') and Ullinshov ('the deity Ullr's hof') (Helleland 1996, 136f.). Places bearing these names were probably the locations of pre-Christian sacred sites, which may have included ritual constructions or buildings. An indication that place names including the term hof were connected to cultic sites is their frequent relation to early medieval churches. In the Swedish province of Jämtland, for instance, there are five places with names including Old Swedish hov. All of these places show clear evidence

5 ef maðr ... læðr hauga eða gerer hus oc kallar horgh. Here quoted from Kong Sverrers Christenret 79. NGL $1,430$.

6 See also the equivalent terms in Old High German, Old Saxon and Old Frisian hof farm, house, court'; Old English hof 'enclosure, dwelling, building, house, temple, sanctuary'. 
of early churches. According to Per Vikstrand (1993), the designation hov at these sites actually refers to Viking Age buildings where pre-Christian rituals had been performed. When the medieval churches were erected, the old name remained. As in many other places in Scandinavia, a cult-place continuity may be discerned at these sites.

Certain ancient poetical traditions also support the idea that hof often had a sacral meaning. In the Eddic poems, for instance, it refers to mythical constructions where the deities dwelt. These poems may have received their literary shape rather late, but their content often reflects pre-Christian notions (see Meulengracht Sørensen 1991a). The Völuspá 7, for instance, mentions that the Æsir gods met at the Iðavöllr ('Idavoll Plain'), where 'they built hörgr and high hof' (peir er hörg oc hof hátimbroðo). We do not get a more precise description in the poem of what hof refers to. The expression hátimbroðr, however, indicates that such construction was 'built high'.

The Eddic poetry thus does not yield an unambiguous idea of the character of the hof, although occasionally the term, as used in this poetry, seems to designate a ritual construction or building. In the earliest Christian skaldic poetry, however, it is apparent that hof refers to a house. According to the poem Austrfararvísur (ca 1020) the Christian scald Sigvatr Pórðarson gives an account of a journey he undertook to the pagan Svípjóð (Sweden) (Skj. A1, 233-40; B1, 220-5). One evening he and his retainers arrived at a place called Hof, looking for room and board; a pagan sacrificial feast, called alfablót, was being celebrated at this place. Snorri Sturluson, who quoted these stanzas in his Óláfs saga Helga (ca 1230), interpreted the word hof in the poem as a place name referring to the entire farm. ${ }^{7}$ In the context of the Austrfararvísur itself, however, it is more relevant to interpret hof as an appellation designating a building. ${ }^{8}$ Immediately after the expression 'to hof I stuck the path', Sigvatr mentions 'the door was shut' (hurd vas aptr). In my opinion the word hurd in this context can only designate 'a house door'.

\section{Designating a Hall Located on the Chieftain's Farm}

In the 13th century prose traditions, hof often designates a pre-Christian huge hall building. These buildings seem to have had a religious function. Inside such buildings were kept ritual objects and images of the gods. Cer-

7 A total of 21 stanzas of Austrfararvísur have been preserved. Snorri Sturluson quoted this poem in his book Óláfs sögu ins helga inni sérstöku. This saga later became a part of Snorri's Heimskringla, in a version called Óláfs saga helga. See Ísl. Fornr. 27, 135ff.

8 In the manuscripts it is written hof, using a lower-case $h$. See Skj. A1, 234. 
emonial banquets were also celebrated there, including drinking rituals. The chieftain, who also was the cult leader, was supposed to sit in his high seat during the ceremonies. This seat seems to have had religious connotations. These large halls were often located on the farms of the chieftains.Kjalnesing a saga 2 (13th century), for instance, mentions that the chieftain (goði) Porgrímr had a hof erected in his courtyard (í túni sínu) in southwestern Iceland (Ísl. Fornr. 14, 7). This house was 100 feet long and 60 feet wide (pat var hundrað fota langt, sextugt a breidd). It had a large hall, with images of the deities and an altar (stallr, stalli) placed in the middle. On this altar were placed a ring and a sacrificial bowl (hlautbolli). Banquets and sacrificial feasts (blótveizlur) were celebrated in this room. ${ }^{9}$

According to Eyrbyggja saga 4 (ca 1250) the chieftain Pórólfr Mostrarskegg also had a hof erected on his farm at Pórsnes, in western Iceland (Ísl. Fornr. 4, 8f.). ${ }^{10}$ It was a large house (mikit hús) with a door in one of the side walls near the gable. Just inside the door stood the high-seat pillars, with the so-called holy nails (reginnaglar) fixed in them; beyond that point the entire building was considered a sanctuary. Inside the hof was a structure or room called the áfhús, built much like a choir loft in churches. In this room the figures of the gods were arranged in a circle around a platform or altar (stallr, stalli), which had sacral objects on it. Ceremonial banquets (blótveizlur) were also celebrated in Pórólfr's hof.

Pórólfr's hof seems to have had a spatial division. Some parts of the building, such as the space beyond the high seat pillars and the áfhús, were regarded as friðarstaðr, ' protected areas', i.e. a sanctuary, while other parts seem to have been regarded as more profane spaces. Perhaps this house could be classified as a multi-functional hall.

The source value of the Sagas of the Icelanders has been much debated by scholars. Olaf Olsen argued that they provide no reliable information at all about pre-Christian religion and ancient customs in Iceland (Olsen 1966). According to him, in describing the hof-building at Pórsnes the medieval author of the Eyrbyggja saga had the Christian church as a mental model. In describing the afhús, the author added 'much like the choir in churches nowadays' (sem nú er sönghús í kirkjum). According to Olsen, this comment

9 Also Ingimundr inn gamli's hof at Vatnsdal, in North-Western Iceland, seems to have been a huge hall building: 'He built a great hof a hundred feet long' (hann reisti hof mikit hundrað fóta langt). This was built at his homestead and 'he called the farm Hof' (Bær sjá skal heita at Hofi). Vatnsdala saga, Ísl. Fornr. VIII, 42.

10 The early chapters of Eyrbyggja saga borrow from Landnámabók S85, H73, M26, Ísl. Fornr. 1, 124-6. Also in this text Pórólfr's hof at Pórsnes is mentioned. 
proves that he actually was describing a church in this passage. This sceptical attitude towards the source value of the Sagas has dominated modern research on ancient Scandinavian religion. Certain scholars have rejected almost all references to 'pre-Christian religion' in the Sagas. In my opinion, this criticism has sometimes gone too far: ${ }^{11}$ information from more direct sources can confirm that some parts of the Sagas may be based on old traditions. Archaeological excavations in Iceland testify that huge halls resembling the hof-buildings described in the Sagas actually once existed there. As alreadymentioned, a Viking Age hall, 36 meters long and 8 meters wide, was discovered in 1908 at the old chieftain site of Hofstaðir, Mývatnssveit, in northern Iceland. The place name Hofstadir, 'the hof place', indicates that this building could in fact be considered a hof. During new excavations at this location in the 1990s, it was discovered that the choir-like structure at the northern gable had an opening into the hall, and thus could be conceived of as an afhús, i.e. the sanctuary part of the hall. ${ }^{12}$ So-called seydir hearths found inside the hall also support the notion that it was used for ceremonial occasions. It is well-known that such hearths were used in connection with ritual food preparation. A minimum of 23 cattle skulls were also retrieved in two clusters from outside the walls of the hall, their location and wear suggesting that they were placed on the turf walls at short intervals along the entire length of the building. This decoration, as well as a complete sheep's skeleton with its head severed, found in one of the rooms adjacent to the hall, indicates that ritual slaughter took place at this building on a seasonal basis. ${ }^{13}$ According to the archaeologists, the hall at Hofstaðir had multiple functions. Most likely it had a political significance, since its central location and monumental size probably functioned as manifestations of power. Perhaps the bloody slaughter, the ritual decapitation and display of the cattle (bull) heads had a similar function. Activities of an everyday character were also carried out there. It was only in connection with the ritual feasts that the hall was transformed into a sanctuary. Thus we may

11 Several scholars have recently been critical of the extreme source critical position of Olsen and other. See e.g. Brink 1996b, 49f.; Jón Hnefill Aðalsteinsson 1998; Jón Viðar Sigurðsson $1999,35 f f$.

12 Olaf Olsen, who proceeded from the results of Daniel Bruun's and Finnur Jónsson's excavation of 1908, argued that the choir-like structure at the northern gable had a door only on the outside, and thus could not be compared with the áfhús mentioned in Eyrbyggja saga. Results from the new excavations indicate that this adjacent room also had a connection directly into the hall. On the new excavations, see e.g.. Adolf Friðriksson \& Orri Vésteinsson 1997; Orri Vésteinsson 2001, 332f.; 2007.

13 See mainly Lucas \& McGovern 2008. 
conclude that the term hof in some sources referred to multi-functional hall buildings situated on the farm of the ruler.

On the basis of the finds at Hofstaðir, Mývatnssveit, the archaeologist Orri Vésteinsson has recently argued that the hall was built in an attempt to create a political and religious centre of resistance to the growing Christian influence in Iceland. ${ }^{14}$ Using a topographical analysis, he argued that farms with designations containing the element hof in Iceland were never part of the original settlement cluster, but rather should be seen as secondary formations. They were established after the farming communities had already been formed. The intention was to create central places in already existing settlements as resistance nods to Christianity. According to Orri, the word hof in place names refers to the feasting hall, which was the arena for different types of socio-political activities. The religious, pagan connotation of the term, however, is first seen in the late 10th century, when these halls became centres of resistance to the new religion.

\section{Referring to a More Specific Cultic Building Detached from the Central Place}

Different types of sources concerning Icelandic conditions thus lead to the conclusion that hof referred to a multifunctional hall building located at a central place. Other sources, however, indicate that the term also designates a more specific cultic building, one whose location is detached from the chieftain's farm, his hall and the major settlements (Vikstrand 2001, 266). Njáls saga 87-88 (13th century), for instance, contains a passage treating the joint hof of Hákon jarl and Guðbrandr, located in Dalir, Norway (Ísl. Fornr. 12, 210, 214f). Within the house were images representing the deities. Thus this house was also called a goðahús, 'gods' house', indicating that it was a more specific cultic building. ${ }^{15}$ One night, when the earl (jarl) was at Guðbrandr's feast (veizla), the outlaw Víga-Hrappr desecrated the hof by setting fire to it. It is quite obvious that this house was located at a distance from the farm and the settlement where the feast was held. Hákon and Guðbrandr discovered the wicked deed only the next morning, after walking to this house. In descriptions of hof-buildings in Iceland, the cultic building similarly sometimes seems to be located at some distance from

14 Orri Vésteinsson 2007

15 There is also other linguistic evidence indicating that the pre-Christian Scandinavians had more specific cultic buildings. For instance Old Norse blóthús can be translated 'sacrificial house, worship house' (cf. ON blóthof). There is also a farm name Gurann (<ON Gudrann 'gudehus') in Botne, Vestfold, indicating the same. See M. Olsen 1926, 240; Andersson 1992, 91. 
the ruler's farm. For instance Hrafnkell Freysgoði's cultic building (called both hof and goðahús) in Hrafnkels saga Freysgoða was situated at an isolated distance from Hrafnkell's farm, below the banks towards the river and above the cliff called Freyfaxahamarr (Jón Helgason 1968, 2f., 28f). In this house the images of the deities were kept. It is not mentioned, however, that banquets were held there. According to Víga-Glúms saga, similar conditions also existed at Pverá, Eyjafjörðr, Northern Iceland. The farm of the chieftain (goði) at Pverá was located at some distance from 'Freyr's sanctuary' (hof Freys) at Hripkelsstaðir (Ísl. Fornr. 9, 34). There is nothing to indicate that this house should be interpreted as a multifunctional hall or festive building. Rather, the dedication of the sanctuary to Freyr intimates that the author interpreted it as a specific religious building. When Víga-Glúm visited the hof at Djúpadalr to swear an oath that he was innocent of Pórvaldr's death, Pórarinn arrived with hundred men to make sure that everything was done in a decent manner. However, only five men followed Víga-Glúm inside the hof (see Ísl. Fornr. 9, 85f.).This suggests that the author thought that the building was rather small, and had a different character from the halls meant for festive entertainment. ${ }^{16}$

New scholarship on place names suggests a similar context of the hof buildings. In his dissertation, Per Vikstrand has shown that the hov names appearing in the Mälar region have a specific local context (Vikstrand 2001, 256ff., 267ff). They do not designate a chieftain's hall located at a central place. Rather, they are related to minor farms, situated separately and at some distance from major settlements. This pattern may be observed for instance in the parish of Vendel, Uppland, Sweden. In addition to the famous funeral field with boat-graves at the medieval church, a hall building was found in connection with a farm and central place called Tuna (Arrhenius

16 When Snorri Sturluson in Óláfs saga Tryggvasonar 68-69 described the hof in Mærin, Inntrøndelag, he produced a similar image. A lot of people were gathered at the sanctuary together with the king: 'King Óláfr now entered the hof, accompanied by few men and some of the farmers' (Óláfr konungr gengr nú í hofit ok fáir menn með honum ok nǫkkurir af bóndum). Ísl. Fornr. $26,317 \mathrm{f}$. It seems as if Snorri thought that this was a quite small building, only used for keeping the images of gods and other ritual objects. It should be noticed that under present church in Mærin traits of a pre-Christian building have been found, together with 19 gold foil figures. It was interpreted as a cult building of hof-type. See Lidén 1969. As far as I know archaeologists do not usually classify it as a multi functional hall building. The hof in Mærin is also mentioned in Landnámabók S 297, H 258, Ísl. Fornr. 1, 307f. In Continental Germanic source there is evidence of small and more specific cultic buildings. In Indiculus superstitionum et paganiarum (MGH LL III II:1, 222f.) dated to 8th century a kind of small houses are mentioned, which also were regarded as sanctuaries (De casulis id est fanis). This information appears in a list of examples describing non-Christian customs and phenomena. Sundqvist 2005a. 
2000). The farm, called Hov, is located a couple of kilometres from the hall and the major settlement, on the other side of Lake Vendel. According to Vikstrand, this Hov place should in any case be related to the central place at Tuna. Most likely there was a more specific cultic building at Hov, where some parts of the rituals were performed. ${ }^{17}$ This cult also concerned the people living at Tuna. A pattern similar to that seen at Vendel appears in several places in Uppland.

These conditions can be contrasted with the case of place names in other parts of Scandinavia. In Jämtland, for instance, the five Hov places are located adjacent to the sites of medieval churches at old central places (see above). In this context it makes sense to conclude that the designation hov refers to a festive hall, used for the convivial feasts which formed a part of the pre-Christian cult (cf. Vikstrand 1993). Jämtland can be described as a segmentary tritbal society led by petty chieftains, who inhabited these cultic sites. A similar situation is found in Uttrøndelag, Norway, where several central places and chieftain farms were called hof (see e.g. Sandnes 1987; Røskaft 2003, 53-76). It is most likely that some of them were also cultic sites, such as Hov at Ålen, Soknedalen and Orkdal and Hove at Byneset and Åsen. There is reason to believe that the names of these farms in some sense referred to the multifunctional hall buildings of the local chieftains, where ceremonial feasts were held during religious gatherings. ${ }^{18}$

\section{Concluding Remarks}

This survey of Old Norse hof (Old Swedish hov) indicates that the term had varying meanings in the sources. In some cases it designates a large hall building erected on the chieftain's farm, where ceremonial banquets and sacrificial feasts were performed and celebrated. Other types of activities probably also took place there, some of which may not be considered religious. In other sources the term hof seems to have designated a more specific and sometimes smaller religious building, located separately at a distance from the central place where the festive hall was most likely situated. Perhaps

17 Vikstrand $(2001,270)$ refers to such cultic buildings which have been found in Borg, Östergötland, and Tissø, Själland.

18 Also written sources indicate that the term hof in Trøndelag sometimes referred to the banquet hall located at the ruler's site. Well-known is the description in Hákonar saga góða 14 of Sigurðr Hlaðajarl's hof at the chieftain residence and farm at Hlaðir, in Uttrøndelag, which seems to be a hall building, intended for ceremonial feasts (Ísl. Fornr. 26, 167f). Whether this description is built on ancient traditions is much debated in research, see e.g. Düwel 1985; Meulengracht Sørensen 1991b; Hultgård 1993; Dillmann 1997; Sundqvist 2005b. 
it was not the locality or size of the building as such that determined the nomenclature hof: it could equally have been certain rooms, sacred objects, a specific architecture or the presence of certain cult leaders which led to such a designation. It is also possible that the meaning of the term varied at different places in Scandinavia, and changed over time. Scholars who have searched for terms in the ancient Scandinavian languages to describe the archaeological finds discovered at cultic sites have often not taken into account the problems involved in the use of linguistic materials. The varying and occasionally unclear meaning of hof makes it hard to connect this term to a specific type of find or structure found at archaeological excavations. This problem is also evident in the use of hörgr and other terms related to the ancient Scandinavian religion.

\section{Bibliography}

\section{Sources}

Brennu-Njáls saga

1971 Íslenzk fornrit 12. Red. Einar Ól. Sveinsson. Reykjavík: Hið íslenzka fornritafélag.

Edda. Die Lieder des Codex Regius. Nebst verwandten Denkmälern.

1983 (1914) Band 1. Text. Red. G. Neckel, 5. verbesserte Auflage von H. Kuhn. Heidelberg: Winter.

Eyrbyggja saga.

1985 Islenzk fornrit 4. Red. Einar Ól. Sveinsson och Matthías Pórðarson. Reykjavík: Hið íslenzka fornritafélag.

Hrafnkels saga Freysgoða.

1968 Nordisk filologi 2. Red. Jón Helgason. København-Oslo-Stockholm: Munksgaard.

Indiculus Superstitionum et Paganiarum.

1883 Monumenta Germaniae Historica. Legum Sectio II. Capitularia Regum Francorum. Tomus I. Denvo edidit Alfredus Boretius. Hanover.

Kjalnesinga saga.

1959 Íslenzk fornrit 14. Ed. Jóhannes Halldórsson. Reykjavík: Hið íslenzka fornritafélag.

Landnámabók

1986 Íslenzk fornrit 1. Ed. Jakob Benediktsson. Reykjavík. 
NGL $=$ Norges Gamle Love indtil 1387. I-III.

1846-1849 Ed. R. Keyser \& P. A. Munch. Christiania.

Njáls saga. See Brennu-Njáls saga above.

Skj = Den Norsk-Islandske Skjaldedigtning 800-1400.

1973 1967-1973 (1912-15) AI-II, BI-II. Ed. Finnur Jónsson. Köbenhavn: Rosenkilde \& Bagger.

Snorri Sturluson. Edda.

1900 Ed. Finnur Jónsson. København: Gad.

Snorri Sturluson. Heimskringla I-III.

1979 (1941, 1945, 1951) Íslenzk fornrit 26-28. Ed. Bjarni Aðalbjarnarson. Reykjavík Hið íslenzka fornritafélag.

Snorri Sturluson. Edda. Prologue and Gylfaginning.

1988 Ed. A. Faulkes. London: Viking Society for Northern Research, University College.

Snorri Sturluson. Edda. Skáldskaparmál. 1: Introduction, Text and Notes.

1998 Ed. A. Faulkes. London: Viking Society for Northern Research, University College.

Snorri Sturluson. Skáldskaparmál. 2: Glossary and Index of Names.

1998 Ed. A. Faulkes. London: Viking Society for Northern Research, University College.

The Poetic Edda

1996 Transl. C. Larrington. Oxford: University press.

Vatnsdala saga

1939 Íslenzk fornrit 8. Ed. Einar O. Sveinsson. Reykjavík: Hið íslenzka fornritafélag.

Víga-Glúms saga. Eyfirđinga sögur.

1956 Íslenzk fornrit 9. Ed. Jónas Kristjánsson. Reykjavík: Hið íslenzka fornritafélag.

Literature

Adolf Friðriksson \& Orri Vésteinsson.

1997 Hofstaðir Revisited. - Norwegian Archaeological Review 30, 105-12.

\section{Andersson, Thorsten}

1992 Kultplatsbeteckningar i nordiska ortnamn, - G. Fellows-Jensen \& B. Holmberg (eds.), Sakrale Navne, 77-105. (NORNA-rapporter 48.) Uppsala: NORNA-förlaget. 


\begin{abstract}
Andrén, Anders
2002 Platsernas betydelse. Norrön ritual och kultplatskontinuitet. - Kristina Jennbert, Anders Andrén \& Catharina Raudvere (eds), Plats och praxis. Studier av nordisk förkristen ritual, 299-342. (Vägar till Midgård 2.) Lund: Nordic Academic Press.
\end{abstract}

\title{
Arrhenius, Birgit
}

2000 Tuna och Husby i Vendel. - Michael Olausson (ed.), En bok om Husbyar. Avdelningen för arkeologiska undersökningar, 93-100. (Skrifter nr 33.) Örebro: Riksantikvarieämbetet.

\section{Brink, Stefan}

1996a Political and Social Structures in Early Scandinavia. A SettlementHistorical Pre-Study of the Central Place. - Tor 28, 235-81.

1996b Forsaringen - Nordens äldsta lagbud. - Else Roesdahl \& Preben Meulengracht Sørensen (eds), Beretning fra femtende tværfaglige vikingsymposium, 27-55. Højbjerg: Hikuin; Aarhus: Afdeling for Middelalderarkæologi, Aarhus Universitet, cop .

\section{Bruun, Daniel \& Finnur Jónsson}

1909 Om hove og hovudgravninger på Island. - Aarbøger for nordisk Oldkyndighed og Historie, 245-316. (II Række. 24. Bind.) Kjøbenhavn: Nordiske Oldskriftselskab.

\section{Christensen, Tom}

1991 Lejre Beyond Legend - The Archaeological Evidence. - Journal of Danish Archaeology 10, 163-85.

1997 Lejrehallen. - Johan Callmer \& E. Rosengren (eds), '... gick Grendel att söka det höga huset ...'. Arkeologiska källor till aristokratiska miljöer $i$ Skandinavien under yngre järnålder. Rapport från ett seminarium i Falkenberg 16-17 november 1995, 47-54. (Hallands länsmuseers Skriftserie No 9/GOTARC C. Arkeologiska skrifter. No 17.) Halmstad: Hallands länsmuseer.

\section{Dillmann, François-Xavier}

1997 Kring de rituella gästabuden i fornskandinavisk religion. - Anders Hultgård (ed.), Uppsalakulten och Adam av Bremen, 51-73, Nora: Nya Doxa.

\section{Düwel, Klaus}

1985 Das Opferfest von Lade. Quellenkritische Untersuchungen zur germanischen Religionsgeschichte. (Wiener Arbeiten zur germanischen Altertumskunde und Philologie 27.) Wien: Karl M. Halosar.

\section{Gehl, Walther}

1941 Das Problem des germanischen Tempels. -Zeitschrift für deutsches Altertum 78, 37-49. 


\section{Grimm, Jakob}

1835 Deutsche Mythologie. Göttingen: Dieterich.

\section{Heggstad, Leiv et al.}

1993 (1930) Norrøn ordbok. Oslo: Samlaget.

\section{Helleland, Botolv}

1996 Ullins vang og Njords hov. Heidne gudar på kyrkjebakken? - Magnus Rindal (ed.), Fra hedendom til kristendom. Perspektiver på religionsskiftet i Norge, 125-40. (KULT-serien 11.) Oslo: Ad Notam Gyldendal.

\section{Herschend, Frands}

1993 The Origin of the Hall in Southern Scandinavia. - Tor 25, 175-199.

1995 Hus på Helgö. - Fornvännen 90, 221-228.

1997 Livet $i$ hallen. Tre fallstudier $i$ den yngre järnålderns aristokrati. (OPIA 14. Institutionen för arkeologi och antik historia.) Uppsala: Uppsala universitet.

1998 The Idea of the Good in Late Iron Age Society. (OPIA 15. Institutionen för arkeologi och antik historia.) Uppsala: Uppsala universitet.

1999 Halle. - Heinrich Beck et al. (eds), Reallexikon der Germanischen Altertumskunde. (Band 13.) Berlin-New York: de Gruyter.

\section{Hultgård, Anders}

1993 Altskandinavische Opferrituale und das Problem der Quellen. - Tore Ahlbäck (ed.) The Problem of Ritual, 221-59. (Scripta Instituti Donneriani Aboensis, XV.) Stockholm: Almqvist \& Wiksell.

1996 Fornskandinavisk kult - finns det skriftliga källor? - Kerstin Engdahl \& Anders Kaliff (eds), Religion från stenålder till medeltid, 25-57. (Riksantikvarieämbetet. Arkeologiska undersökningar. Skrifter nr 19.) Linköping: Avd. för arkeologiska undersökningar, Riksantikvarieämbetet.

\section{Jón Hnefill Aðalsteinsson}

1998 A Piece of Horse Liver. Myth, Ritual and Folklore in Old Icelandic Sources. Reykjavík: University of Iceland Press .

\section{Jón Viðar Sigurðsson}

1999 Chieftains and Power in the Icelandic Commonwealth (The Viking Collection 12.) Odense: Odense University Press.

\section{Jørgensen, Lars}

1998 En storgård fra vikingetid ved Tissø, Sjælland - en foreløbig præsentation. - Lars Larsson \& Birgit Hårdh (eds), Centrala platser - Centrala frågor. Samhällsstrukturen under Järnåldern. En Vänbok till Berta Stjernquist, 233-48. (Uppåkrastudier 1.) Stockholm: Almqvist \& Wiksell International.

2002 Kongsgård - kusted - marked. Overvejelser omkring Tissøkompleksets struktur og funktion. - Kristin Jennbert, Anders Andrén \& 
Catharina Raudvere, Plats och praxis - studier av nordisk förkristen ritual, 215-47. (Vägar till Midgård 2.)Lund: Nordic Academic Press.

\section{Keyser, Rudolph}

1847 Nordmændenes Religionsforfatning i Hedendommen, Oslo: Dybwad.

\section{La Farge, Beatrice \& John Tucker}

1992 Glossary to the Poetic Edda. (Skandinavistische Arbeiten 15.) Heidelberg: Winter.

\section{Larsson, Lars \& K.-M. Lenntorp}

2004 The Enigmatic House. - Lars Larsson (ed.), Continuity for Centuries. A Ceremonial Building and its Context at Uppåkra, Southern Sweden, 3-48. (Uppåkrastudier 10.) Stockholm: Almqvist \& Wiksell International.

\section{Lidén, Hans-Emil}

1969 From Pagan Sanctuary to Christian Church. The Excavation of Mære Church in Trøndelag - Norwegian Archaeological Review (2), 3-32.

\section{Lindeblad, Karin}

1997 Gården från yngre järnåldern - skede 3. -Karin Lindeblad \& Ann-Lili Nielsen (eds), Kungens gods i Borg. Om utgrävningarna vid Borgs säteri i Östergötland, 31-44. Linköping: Avd. för arkeologiska undersökningar.

\section{Lucas, Gavin \& Thomas McGovern}

2008 Bloody slaughter: Ritual decapitation and display at the Viking settlement of Hofstaðir, Iceland. - European Journal of Archaeology 10 (1), 7-30.

\section{Meulengracht Sørensen, Preben}

1991a Om eddadigtenes alder. - Gro Steinsland et al. (eds), Nordisk hedendom. Et symposium, 303-19, Odense: Odense universitetsforlag.

1991b Håkon den gode og guderne. Nogle bemærkninger om religion og centralmagt i det tiende århundrede - og om religionshistorie og kildekritik. - P. Mortenssen \& B. M. Rasmussen (eds), Fra Stamme til Stat i Danmark II. Høvdingesamfund of kongemagt, 235-44. (Jysk Arkæologisk Selskabs Skrifter XXII:2.) Århus: Jysk Arkæologisk Selskab.

\section{Nielsen, Ann-Lili}

1996 Hedniska kult- och offerhandlingar i Borg. - Kerstin Engdahl \& Anders Kaliff (eds), Religion från stenålder till medeltid, 89-104. (Riksantikvarieämbetet. Arkeologiska undersökningar. Skrifter nr 19.) Linköping: Avd. för arkeologiska undersökningar, Riksantikvarieämbetet.

\section{Ohlmarks, Åke}

1936 Isländska hov och gudahus. - Bidrag till nordisk filologi tillägnade E. Olsson, 339-55. Lund: Gleerup. 


\section{Olsen, Magnus}

1926 Ættegård og helligdom. Norske stedsnavn sosialt og religionshistorisk belyst. (Instituttet for sammenlignende kulturforskning. A. Forelesninger.

9a.) Oslo: H. Aschehoug \& Co.

\section{Olsen, Olaf}

1966 Hørg, hov og kirke. Historiske og arkæologiske vikingetidsstudier. København: Gad.

\section{Orri Vésteinsson}

2001 The Conversion of the Icelanders. - Przemysław Urbanczyk (ed.), Europe around the Year 1000, 325-42. Warszawa: Wydawnictwo DIG.

2007 'Hann reisti hof mikið hundrað fóta langt ...'. Um uppruna hof-örnefna og stjórnmál á Íslandi á 10.öld. - Guðmundar J. Guðmundsson \& Páll Björnsson (eds), Saga Tímarit Sögufélags. XLV:1, 53-91, Reykjavík: Sögufélag.

\section{Rostvik, Allan}

1967 Har och harg. (Acta Academiae Regiae Gustavi Adolphi. XLIV. Studier till en svensk ortnamnsatlas utgivna av Jöran Sahlgren. 11.) Uppsala: Uppsala Universitet.

\section{Røskaft, Merete}

2003 Maktens landskap. Sentralgårdar i Trøndelag ved overgangen fra vikingtid til kristen middelalder, ca. 800-1200. (No.39 Skriftserie fra Historisk institutt.) Trondheim: Norges teknisk- naturvitenskaplige universitet.

\section{Sandnes, Jørn}

1987 Hedensk kulthus og kristen kirke. - Jan Ragnar Hagland \& Jan Terje Faarlund \& Jarle Rønhovd, Festskrift til Alfred Jakobsen, 144-52. Trondheim: Tapir Forlag.

SOL $=$ Svenskt ortnamnslexikon

2003 Mats Wahlberg (ed.), Uppsala: Språk- och folkminnesinstitutet (SOFI).

\section{Sundqvist, Olof}

2005a Tempel. - H. Beck et al. (eds.), Reallexikon der Germanischen Altertumskunde. Band 30, 327-38. Berlin-New York: De Gruyter.

2005b Sagas, Religion and Rulership. The Credibility of the Description of Ritual in Hákonar saga goða. -J. Quinn et al. (eds), Viking and Medieval Scandinavia 1, 225-50. Turnhout: Brepols.

\section{Söderberg, Bengt}

2005 Aristokratiskt rum och gränsöverskridande. Järrestad och sydöstra Skåne mellan region och rike 600-1100. (Riksantikvarieämbetet Arkeologiska undersökningar Skrifter. No 62.) Stockholm: Riksantikvarieämbetets förlag. 


\section{Thümmel, Albert}

1909 Der germanische Tempel. - Beiträge zur Geschichte der deutschen Sprache und Literatur (35), 1-123.

\section{Vikstrand, Per}

1993 Förkristna sakrala ortnamn i Jämtland. - Namn och bygd 81, 49-84.

2001 Gudarnas platser. Förkristna sakrala ortnamn i Mälarlandskapen. (Acta academiae regiae Gustavi Adolphi. LXXVII. Studier till en svensk ortnamnsatlas utgivna av Thorsten Andersson. 17.) Uppsala: Uppsala Universitet.

\section{Vries, Jan de}

1961 Altnordisches etymologisches Wörterbuch, Leiden: Brill.

1970 (1956-1957) Altgermanische Religionsgeschichte I-II. (Grundriss der germanischen Philologie 12/1-2.) Berlin: de Grüyter. 


\section{Appendix: Figures}

Figure 1. Find distribution in the hall on Foundation Ia at Helgö. (a) Fragments of filigree glass claw and cone beakers = open triangle. (b) Guldgubbar = open square; weapons $=$ filled square. (c) Knives = filled triangle; loom-weights and wetstones = a dot. (d) Density map of the kind of distribution. The first isarithmic curve marks areas with at least 1 find per $\mathrm{m}^{2}$. The most dense square metre contains 8 finds, and the entire house (125 $\mathrm{m}^{2}$ ) contains 90 finds. The ' $\mathrm{H}$ ' marks a presumed position of the high seat. After Herschend 1998.

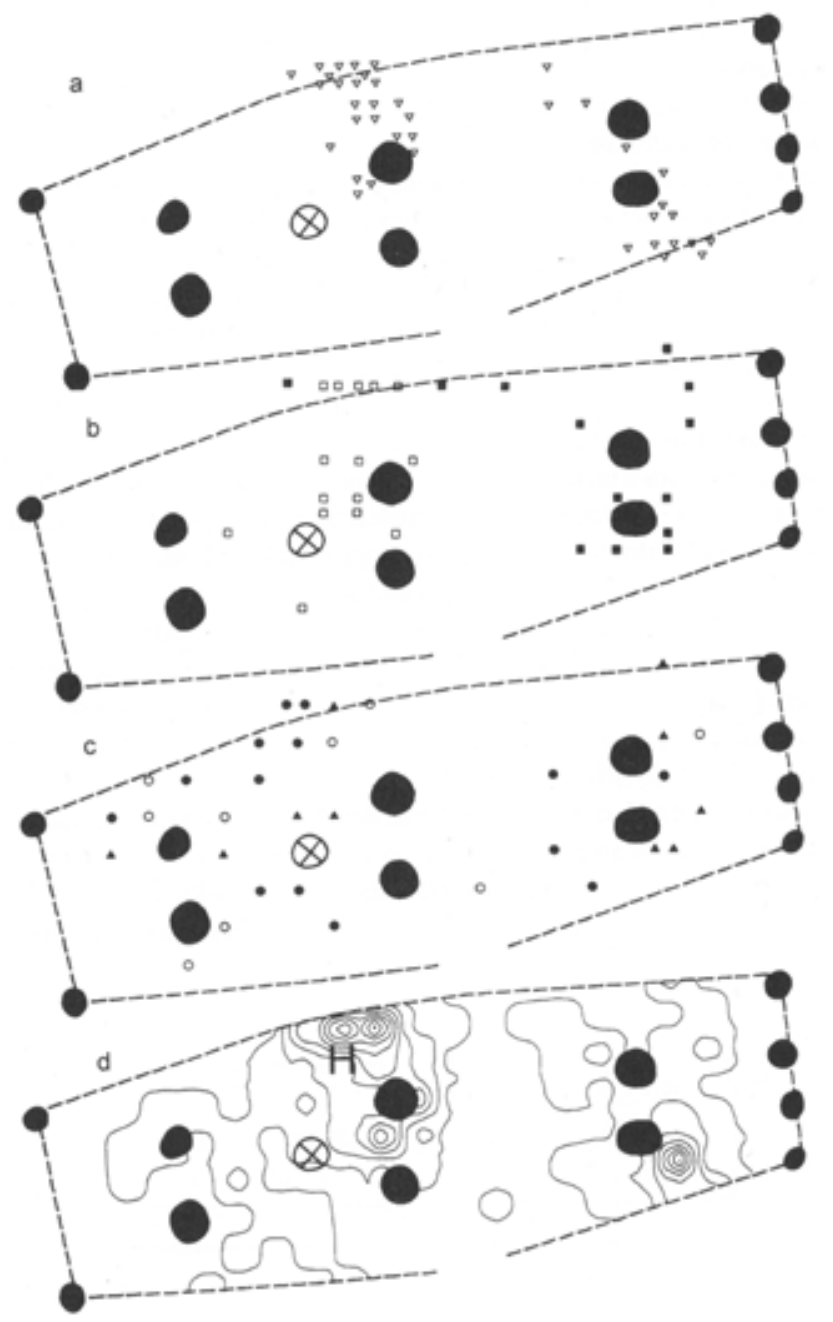


Figure 2. A presumed cultic house in Borg, Östergötland. Illustration Richard Holmgren. After Lindeblad 1997.

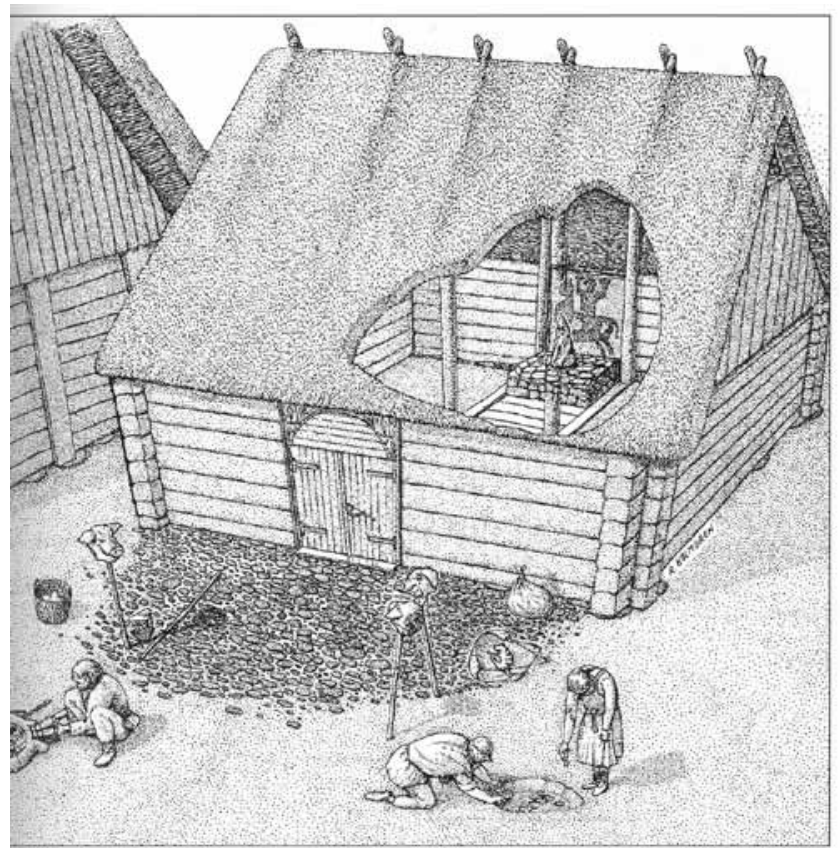

Figure 3. A presumed cultic house in Uppåkra, Scania. Illustration Loïc Lecareux. After Larsson \& Lenntorp 2004.

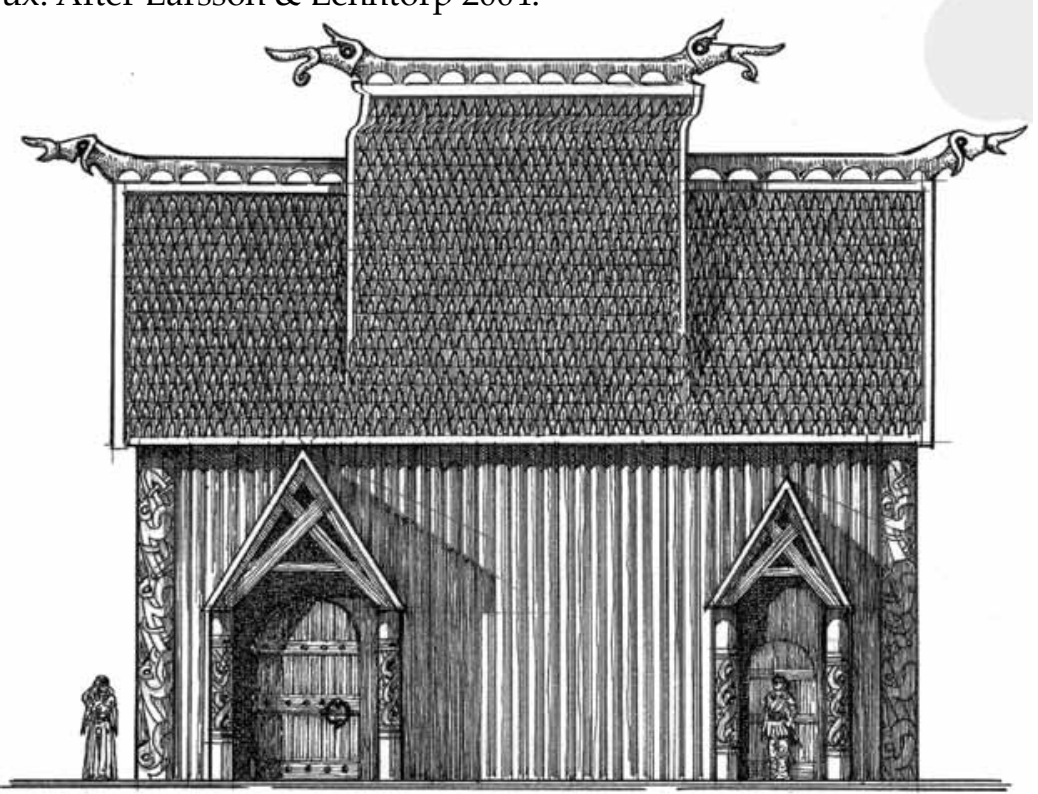


Figure 4. The ritual area in Järrestad, Scania, with hall, enclosure and small cultic building. A similar structure is found at Lake Tissø, Zealand. After Söderberg 2005.

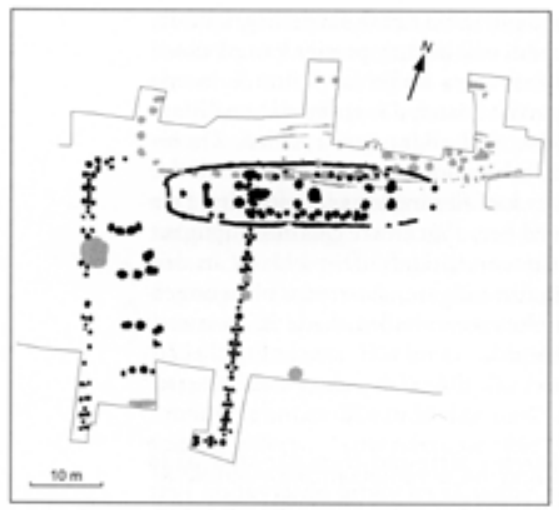

Jărrestad skede 2

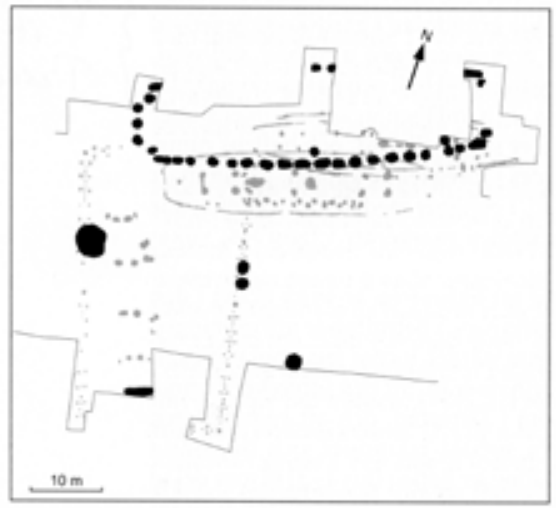

Mrrestad skede 3

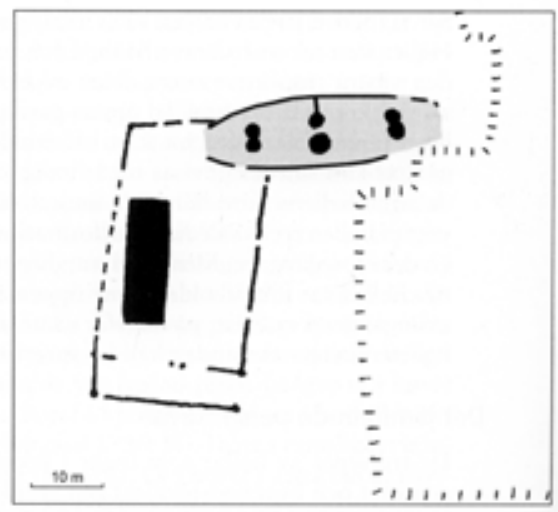

Tissa skede 2

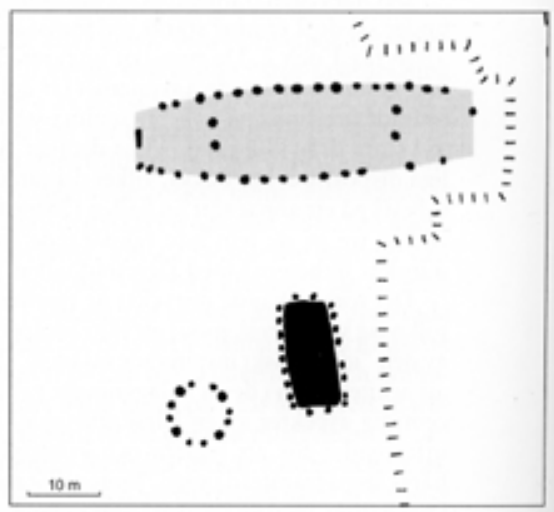

Tisse skede 4 